\title{
BANKACILIK SEKTÖRÜNDE ÖRGÜTSEL ADALET, ÖRGÜTSEL GÜVEN VE ÖRGÜTSEL BAĞLILIK ARASINDAKİ İLIŞKININ İNCELENMESİ
}

\author{
Duygu TUNALI ${ }^{1}$ \\ Ayşegül PEKER ${ }^{2}$
}

\section{Özet}

Bu çalışmada, örgütler için etkinlik ve verimlilik açısından önemli unsurlar arasında yer alan örgütsel adalet, örgütsel güven ve örgütsel bağlılık kavramları ele alınarak, çalışanlar ve kurum bakımından birbirleri ile olan ilişskileri incelenmiştir. Bu amaçla 44 maddeden oluşan 5'li likert tipi anket formu hazırlanmış ve Sivas İli'ndeki özel ve kamu bankalarından yargısal olarak seçilen 7 kamu, 4 özel banka şubesi çalışanlarına uygulanmıştır. Gönüllülük esasına göre toplanan ve geçerli olarak değerlendirilen toplam 130 çalışandan elde edilen veriler yapısal eşitlik modellemesi tekniği ile analiz edilmiş ve analizde LISREL 8.72 programı kullanılmıştır. Yapılan analizler sonucunda örgütsel adalet ve örgütsel güven arasında anlamlı bir ilişki olduğu ve örgütsel güven ile örgütsel bağlılığın alt boyutlarını oluşturan normatif bağlılık, duygusal bağlılık ve devam bağlılı̆̆ı arasında da anlamlı ilişkiler olduğu ortaya konulmuştur.

Anahtar Kelimeler: Örgütsel Adalet, Örgütsel Güven, Örgütsel Bağlılık, Yapısal Eşitlik Modellemesi

\section{Abstract}

In this study, the relationship between organizational justice, organizational commitment and organizational trust, which are amongst important elements in terms of efficiency and productivity for organizations, were examined with regard to employees and institutions. For this purpose, a 5-point Likert-type questionnaire consisting of 44 items was prepared and applied to 7 public banks and 4 private banks branch employees who were selected judicially from private and public banks in Sivas Province. The data obtained from a total of 130 employees, which were collected on a voluntary basis, and evaluated as valid, were analyzed by structural equation modeling technique and LISREL 8.72 program was used in the

${ }^{1}$ Dr. Öğr. Üyesi. Anadolu Üniversitesi, İktisadi ve İdari Bilimler Fakültesi, İşletme Bölümü, Sayısal Yöntemler ABD, Eskişehir, dcoskun@anadolu.edu.tr

${ }^{2}$ Öğr. Gör. Sivas Cumhuriyet Üniversitesi, Yıldızeli Meslek Yüksekokulu, Yönetim ve Organizasyon Bölümü, Sivas, apeker@ cumhuriyet.edu.tr 
analysis. As a result of the analyzes, it was found that there is a significant relationship between organizational justice and organizational trust and there are also significant relationships between organizational trust and normative commitment, emotional commitment and continuity commitment which consist the subscales of organizational commitment.

Keywords: Organizational Justice, Organizational Trust, Organizational Commitment, Structural Equation Modeling

\section{GíRiş}

Örgütlerin varlık sebepleri insandır ve bu nedenle örgütler, kendi kurumsal yapıları içerisinde özellikle insan dinamizmine son derece ihtiyaç duymaktadır. Bir örgütün kurulmasından ziyade devamlılığı en önemli faktörler arasındadır. Bu durum insan ilişkilerinin ve iletişiminin son derece önemli olduğunu ortaya koymaktadır. Örgütün devamlılığı için amaçları ve hedefleri açıkça ortaya konulmalı ve bu amaçlar doğrultusunda çalışanlar motive edilmelidir. Çalışanların motivasyonu örgüt içerisinde adaletli ve güvene dayalı bir ilişki ile ortaya çıkar. Örgütsel adalet kavramını ele alan çalışmalarda, birçok değişkenin örgütsel adalet algısını etkilediği ortaya konmaktadır (Işık vd., 2012:255). Bunların başında ise örgüte duyulan güven gelmekle birlikte, aynı zamanda bu güven duygusunun çalışanların; kurumlarına ve çalışanlarına olan güvenlerini olumlu bir şekilde etkilediği ve verimliliklerini arttırdığ belirlenmiştir (İnan ve Çelik, 2018:24). Örgüte duyulan güvenin de çalışanların örgüte olan bağl1lığını artırdığı görülmektedir. Örgütsel bağlılık; "iş görenin örgütsel amaçlar için özveriyle çalışması, örgütüne karşı sadakat duygusu, örgütün değer ve amaçlarını kabullenmesi, içselleştirmesi, örgütle bütünleşmesi, özdeşleşmesi, güç birliği yapması, örgüt üyeliğini devam ettirmek için güçlü bir istek duyması" gibi tanımlarla ifade edilmektedir (Gülova ve Demirsoy, 2012:50).

İnsan ilişkilerinin ve kurum içi iletişimin en yaygın olduğu örgütlerden birisi de bankalardır. Bankalar finans sektöründe önemli bir yere sahiptir ve bu nedenle etkinlik ve verimliliklerini arttırarak kendilerini geliştirmeleri ve insan kaynakları yapısını değişime uygun nitelikte bir hale getirmeleri gerekmektedir (Mete ve Aksoy, 2015:234). Tüm sektörlerde olduğu gibi insana dayalı bir yapıda olduğundan, bankacılık sektöründe de çalışanların kurum içi tutum ve davranışlarının örgüt açısından önemi göz ardı edilemez.

Bankacılık, hizmet sektörü olduğundan çalışan sayısı çok olan kurumlar arasında olup, çalışanlar arasında kuruma bağlılık ve aidiyet duygusunun en fazla olması gereken sektörlerden biridir. Bu nedenle çalışanların aidiyet duygusunun geliştirilebilmesi için hem yönetim hem de 
insan kaynakları bölümlerinin iş birliği içerisinde çalışarak, insan odaklı bir yönetim anlayışını benimsemeleri gerekir. $\mathrm{Bu}$ şekilde bir yönetim anlayışı kurum içerisinde çalışanların birbirleriyle ve yöneticileri ile iletişimini olumlu kılar dolayısıyla çalışanların örgüte bağlılığını ve aidiyetini artırır. Bankalarda çalışanların beklentisi, kurum içindeki her pozisyonda örgütsel adaletin sağlanmasıdır. Örgütsel adaletin sağlanması, çalışanlarda kuruma karşı güven oluşturacaktır ve oluşan örgütsel güven, çalışanların kuruma olan bağlılı̆̆ını artırır.

Literatürde özellikle çalışmada ele alınan faktörlerinin birbirleri ile ilişkileri üzerine yapılan çalışma sayısı az olup özellikle bankacılık sektöründe yapılan çalışma sayısı çok azdır. Çalışmada uygulanan model ve analizi ile bağlantılı literatürde önceden yapılmış bir araştırmaya rastlanmadığından ele alınan kavramlarla ilgili yeni bir model önerilmiştir.

Bu çalışmada Sivas ilindeki özel ve kamu banka çalışanlarına anket uygulanmış olup, sağlanan veriler yapısal eşitlik modellemesi ile analiz edilmiştir. Yapılan incelemeler sonucunda örgütsel adalet ile örgütsel güven arasında ve örgütsel güven ile örgütsel bağlılık arasında doğru yönlü bir ilişki olduğu tespit edilmiştir.

\section{LİTERATÜR}

Literatürde örgütsel adalet, örgütsel güven ve örgütsel bağlllık kavramları ile alakalı yapılan pek çok çalışmaya rastlanmıştır. Bu çalışmalar incelenerek öncelikle bu kavramları açıklayanlar; ardından bu kavramları birlikte ele alarak aralarındaki ilişkileri inceleyen araştırmalar değerlendirilmiştir.

Şahin ve Taşkaya (2010:86) örgütsel adaleti, genel anlamda "bireyin örgütündeki uygulamalarla ilgili algılamalarına atıfta bulunan ve Adams'ın Eşitlik Teorisi'ne dayalı olan bir kavramdır” şeklinde tanımlamıştır. Khan ve Habib (2012:36)'e göre örgütsel adalet, insanların eşit ölçüde muamele görüp görmediğinin ve insanların bu durumu ne ölçüde algıladığını yansıtır. Greenberg (1993:85) ve Colquitt (2001:388-389)'e göre örgütsel adalet; dağıtımsal adalet, işlemsel adalet ve etkileşimsel adalet olarak üç boyutta incelenerek bu alanda geliştirdikleri ölçekle, yapılan çalışmalarda sıkça referans olarak gösterilmektedir.

Örgütsel güven kavramı ile ilgili Cook ve Wall (1980), birey ve gruplar arası güvenin örgütün uzun vadede yararı için önemli olduğunu ve örgüt elemanlarının kendi aralarında huzurlu olmaları açısından kayda değer bir bileşen olduğunu ifade etmektedir. Chen vd. (2012:409) için örgütsel güven ise, örgütlerde kurulan ilişkilerin güvene dayanması gerektiğini, bu nedenle çalışanların liderlerine ve örgütün tamamına güven duyan; örgütlerine hem duygusal açıdan örgüte bağlı, hem de yaptıkları işten memnun olan ve örgütlerinden şikâyet etmeyen ve işi bırakmayı istemeyen çalışanlar yetiştirmeyi ifade etmektedir. Üstün (2015)'e göre, örgütte 
güven ortamının yaratılması için, üyelerin davranış ve beklentileri üzerinde kurumun sistem, süreç ve politikaları önemli bir etki oluşturmaktadır.

Örgütsel bağlılık Meyers ve Allen (1991:62)'e göre, kuruma mensup olmayı devam ettirmek için bir zorunluluk, bir istek veya ihtiyaçtan meydana gelmektedir. Meyer ve Allen (1991), örgütsel bağlılı̆̆ın duygusal, devam ve normatif bağl1lık olmak üzere alt boyutları olduğunu açıklamıştır (Mete ve Aksoy, 2015:234).

Duygusal bağlılığa etki eden faktörler Allen ve Meyer (1990)'e göre, iş zorluğu, rol belirginliği, arkadaş bağ l1lığı, yönetimin yeni fikirlere karşı tutumu, hedef farklılığ1, etik ve adalet, kişisel önem, geri dönüş ve katılımdan meydana gelmektedir (Oktay ve Gül, 2003:408). Kaya ve Selçuk (2007:180), duygusal bağlılığ1, bireylerin, kurumun hedeflerini de gözeterek güçlü ve pozitif bir tutum sergilemeleri ve kendilerini kurumla özdeşleştirerek faaliyet göstermeleri neticesinde duygusal bağ oluşturmaları şeklinde tanımlamışlardır. Böylece çalışanların üzerinde bir aidiyet duygusu oluştuğunu ifade etmektedirler. Normatif bağl1lı̆g ise, çalışanların kendilerini kuruma karşı sorumlu hissettikleri ve bu çerçevede görevlerini yerine getirmekle yükümlü olduklarını belirtmiş olup, kendilerini organizasyonu içerisinde oldukları müddetçe üyeliklerini devam ettirme zorunluluğu duydukları bir bağlılık türü olarak tanımlamışlardır. Devam bağlılığını ise, çalışanların işi bırakmaları halinde karşı karşıya kalacakları maliyetin daha fazla olacağı fikri ile örgütte mensup olarak kalma durumu olarak ifade etmişlerdir. Çakar ve Ceylan (2005:56), duygusal bağlılığı; çalışanın örgüte katılarak kendisini tamamlayabildiği ve bu şeklide güçlü duygusal bağl1lığa sahip olan bireylerin, kalmayı istedikleri için çalışmayı sürdürdükleri şeklinde ifade etmişlerdir. Devam bağlılığını, çalışanların örgütten ayrılmaları durumunda kendilerine mal olacakları durumların farkında olmalarından dolayı, kurumda kalmayı sürdürmeleri gerektiği inancına dayalı bir bağl1lık türü olarak ifade etmektedirler. Normatif bağlılı̆ğ ise, çalışanların örgütte sürdürülebilirliklerine yönelik algıladıkları zorunluluklar şeklinde ifade etmektedirler. Bu bağlılık türünde çalışan minnet, mecburiyet, görev ve sorumluluk gibi nedenlerle örgütte çalışması gerektiğini düşünür (Polatçı vd., 2014:283).

Literatürde örgütsel adalet, güven ve bağlılık kavramları arasındaki karş1lıklı ilişkiler çeşitli analiz teknikleriyle ele alınıp amaca göre farklı çalışmalar yapılmıştır.

Yıldız (2013) Bolu ilinde görevli 171 sınıf öğretmeni ile yaptığı araştırmada ilişkisel tarama modelini kullanmış ve örgütsel adalet ve örgütsel güven arasında doğru yönlü güçlü bir ilişki olduğunu tespit etmiştir.

Aksoy (2017), çalışanların örgüte karşı adalet ve güven algıları arasındaki ilişkiyi incelemek adına yaptığı çalışma ile ilgili model oluşturmuş ve bu araştırma sonucunda elde 
ettiği verileri, araştırmanın amacı doğrultusunda SPSS 18.0 paket programı ile test etmiştir. Çalışmasında temel istatistik tekniklerinden bazılarını kullanmış ve örgüt çalışanlarının adalet ve güven algıları arasında doğru yönlü kuvvetli bir ilişki olduğu sonucuna ulaşmıştır.

Şahin ve Kavas (2016), öğretmeler ile oluşturdukları çalışma grubu ile örgütsel bağlılık ve adalet arasındaki ilişkiyi incelemiş ve pozitif yönlü yüksek düzeyde anlamlı ilişkiler olduğu sonucuna ulaşmıştır.

Demirel'in (2008) yaptığı araştırmanın amac1, örgütsel güvenin örgütsel bağl1lığa etkisini ortaya koymaktır. Bu amaçla, 141 tekstil çalışanı ile yapılan anket sonucunda örgüte duyulan güvenin duygusal ve devam bağlılığı ile anlamlı ilişkili olduğu, normatif bağlılıkla ise anlamlı bir ilişki olmadığını belirlemiştir.

Akgündüz ve Güzel (2014), örgütsel adalet ile örgütsel bağlılık arasındaki ilişkide örgütsel güvenin aracılık etkisini belirlemek üzere yaptığı çalışmada yapısal eşitlik modellemesini kullanarak dağıtımsal adaletin ve işlemsel adaletin örgütsel bağlılığı pozitif etkilediğini belirlemişlerdir. Aracı değişken olarak örgütsel güven eklendiğinde yalnızca işlemsel adalet ile örgütsel bağlılık arasında örgütsel güvenin aracılık rolüne sahip olduğunu belirlemişlerdir.

Candan (2014), faktör analizi, korelasyon ve regresyon analizleri ile örgütsel adalet, güven ve bağlılık üzerine yaptığı çalışmada, bu kavramları alt boyutları ile ele alıp, anlamlı ve anlamlı olmayan ilişkileri yorumlamıştır.

Mete ve Aksoy (2015) kamu ve özel banka personeli ile yaptıkları çalışmalarında, örgütte adalet, güven ve bağlılık algılamalarının; demografik özellikler ve iş tecrübesine göre değişiklik gösterip göstermediğini araştırmış ve adalet algısı açısından güven ile bağlılık arasında doğru yönlü bir ilişki olduğunu belirlemişlerdir.

Literatür incelendiğinde çalışmalar incelendiğinde; örgütsel adalet, örgütsel bağl1lık ve örgütsel güven kavramlarının çalışmalarda sıkça incelendiği ve literatürde farklı teknikler kullanılarak değişik uygulamalar yapıldığı görülmüştür. Bu üç kavramın birlikte yapısal eşitlik modellemesi ile analiz edildiği çalışmalar çok kısıtlı olup, söz konusu kavramların alt boyutları farklı şekilde değerlendirilmiştir. Bu çalışma, adı geçen üç kavram ve alt bileşenleri birlikte ele alınarak yapısal eşitlik modellemesi uygulanmasından dolayı özgünlük göstermektedir. Diğer yapılan çalışmalara nazaran yapısal eşitlik modellemesi, çoklu değişkenleri nedensel süreçler bakımından incelemesinden dolayı bu analiz metodu karmaşık yapıdaki birbirlerinden bağımsız olan değişkenler ve alt bileşenlerin analizini, eş zamanlı bir şekilde regresyon ya da faktör analizlerinin yapılmasına olanak sağlayarak hepsini tek bir analizde birleştirmektedir. Literatürde; bankacılık sektöründe, bu çalışmada oluşturulan model ve değişkenlerinin ele 
alındığı benzer bir çalışmaya rastlanmamıştır. Bu bağlamda önerilen araştırma modelinin literatüre katkı sağlayacağı düşünülmektedir.

\section{ARAŞTIRMA MODELI VE HIPOTEZLER}

Türkiye'de son yıllarda gelişen bankacılık sektörü ve kârlılı̆̆g, piyasada faaliyet gösteren aktörler arasında yoğun rekabet ve çekişmeye sahne olmaktadır. Her geçen zaman pastadan daha fazla pay alabilme mücadelesi, personel başı iş yükünün artmasına sebep olabilmektedir. Geniş anlamda her bir banka kendini daha ileriye taşıyabilme adına aldığı kararların personele uygulanmasında genellikle baskıya varan tutum ve davranışları ortaya çıkarabilmektedir. Genellikle banka politikası ile ilgili kararların belirlenmesi, uygulanabilirliği ve iş akışı tek taraflı olarak yönetici kadrosu tarafından sağlanabilmektedir. Tek taraflı alınan kararların uygulanması ya personelin direnci ya da adapte olamama sorununu da ortaya çıkarabilmektedir. İşlemsel adalet olarak, kararların alınması ile ilgili olan bu durum genellikle memur olarak çalışan personeli çok fazla etkilememektedir. Etkileşimsel adalet açısından ise ülkemizde bankacılık sektöründe kurum kültürünün yeni oturuyor olmas1 yöneticilerin/çalışanların karakteristik özelliklerine göre farklılık gösterebilmektedir. Hatta aynı kurumun farklı şubelerinde bile zıt sonuçlar elde edildiği görülebilmektedir. Bu nedenle bankacıllı sektöründe etkileşimsel adalet ve işlemsel adalet çalışan personel üzerinde kuruma olan güveni etkilemekte sığ kalmaktadır. Aksine dağıtımsal adalet de durum biraz daha farklıdır. İşverenin "eşit işe eşit ücret” ilkesi gereği personel başına düşen iş yükünün adil olarak dağıtılması ve tatminkâr ücretlerin çalışanlara ödenmesi personel açısından kuruma olan güveni artırmakta ve sadakatin pekişmesine zemin hazırlamaktadır. Oluşan bu güven ortamı personel ve kurum arasındaki aidiyeti ve bağl1lığ 1 güçlendirmektedir. Bu durum uzun vadede kurum kültürünün oluşması ve gelişmesini desteklemektedir. Güven ortamının sağlandığı, aidiyetin geliştiği ve kurum kültürünün oturduğu bir çalışma ortamı yaşadığımız dönemin aranılan çalışma ortamlarındandır. Bu sayede aynı tutum ve davranışları benimseyen ofis çalışanları birlikte kurum adına daha kaliteli, daha yenilikçi ve daha katma değerli hizmetler üretebilecektir. Elde edilebilecek toplam fayda kurum bünyesinde zenginleşecek ve kurum hep bir adım ileriye taşınacaktır. Dağıtımsal adalet daha çok alt tabakadaki personel üzerinde ücret, çalışma saati, iş yükü gibi kavramlardan dolayı etkili olduğundan, çalışmada örgütsel adalet kavramını ölçen ifadeler bu alt boyut ile değerlendirilmiştir.

Çalışmada önerilen araştırma modeli ile örgütsel güven üzerinde örgütsel adaletin etkisi olduğu; örgüte olan güvenin ise örgütsel bağlılığı etkilediği test edilmektedir. Örgütsel bağlılık 
da alt boyutları olan duygusal bağlılık, devam bağlılığı ve normatif bağlılık ile modele dahil edilmiştir. Buna göre önerilen araştırma modeli ve oluşturulan hipotezler izleyen biçimdedir.

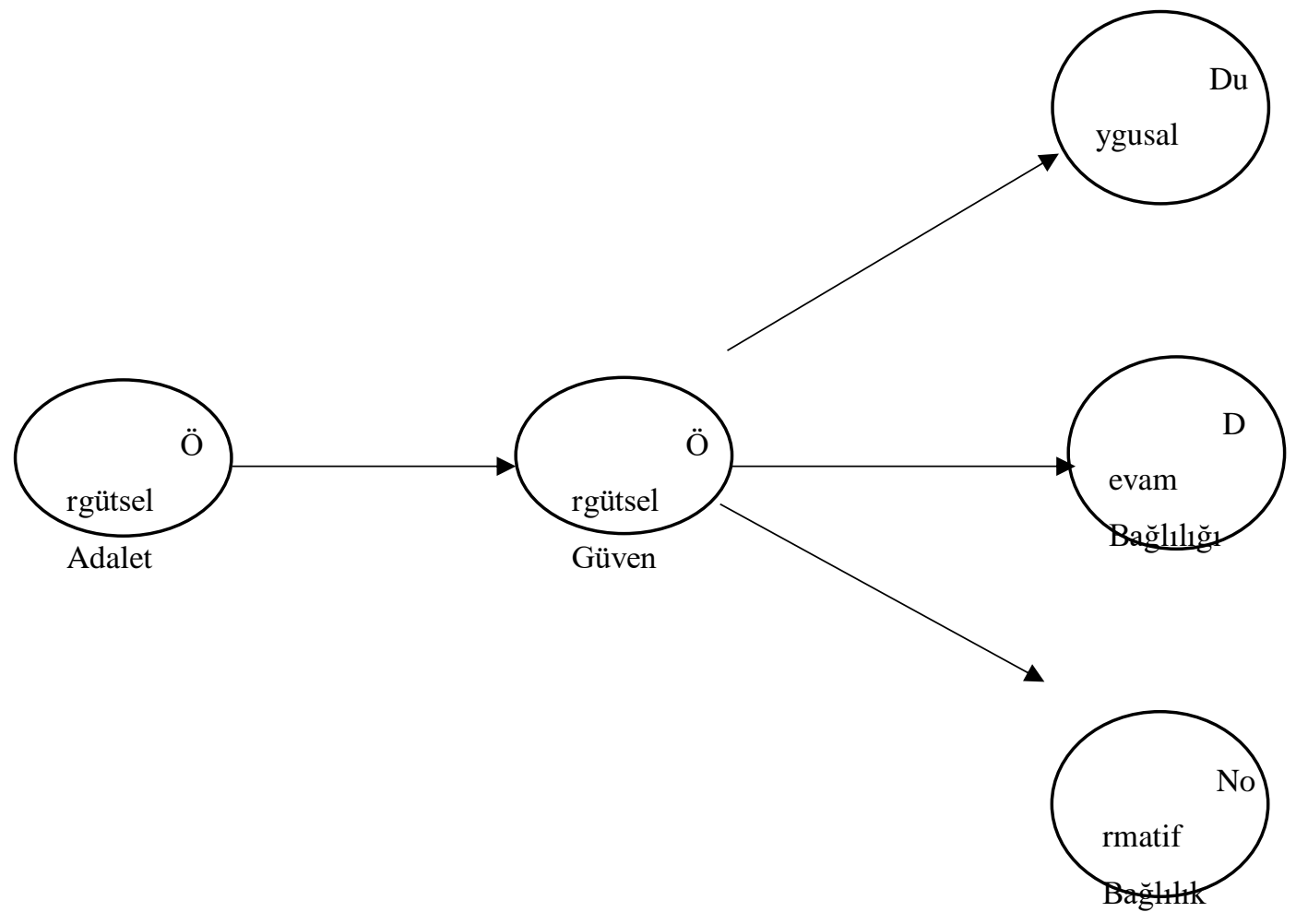

Şekil 1. Araştırma modeli

Araştırmanın hipotezleri aşağıdaki gibidir,

H1: Banka şubelerinde çalışan personele uygulanan örgütsel adalet, örgütsel güveni etkilemektedir.

H2: Banka şubelerinde çalışan personele uygulanan örgütsel güven, örgütsel bağlılığın alt kriteri olan devam bağlılığını etkilemektedir.

H3; Banka şubelerinde çalışan personele uygulanan örgütsel güven, örgütsel bağl1lığın alt kriteri olan normatif bağ $l_{1} l \grave{l g} 1$ etkilemektedir.

H4: Banka şubelerinde çalışan personele uygulanan örgütsel güven, örgütsel bağl1lığın alt kriteri olan duygusal bağ $\operatorname{lilı̆g}_{1}$ etkilemektedir.

\section{YAPISAL EŞITTLIK MODELLEMESİ}

Yapısal eşitlik modellemesi yöntemi, gözlenen değişkenler ile gizil değişkenler arasındaki nedensel ve karşılıklı ilişkileri bir arada test eden modeller için kullanılan ve kapsamı oldukça geniş olan, kovaryans analizi, varyans analizi ve regresyon analizlerinin de yapıldığ 1 istatistiksel bir yaklaşımdır (Çelik ve Yılmaz, 2016:5-6). Yapısal eşitlik modellemesini 
uygulamadan önce bu değişkenler arasındaki neden sonuç ilişkisi ile ilgili modeller path analizi ile kurulur ve bu modelin doğruluğu tespit edilir (Uyar, 2019:48).

Yapısal eşitlik modellemesi, regresyon modelindeki değişkenler arasındaki neden sonuç ilişkisini, faktör analizindeki gizli faktör yapıları ile birlikte kapsamlı olarak tek analizde birleştirmektedir. $\mathrm{Bu}$ araştırmada yapısal eşitlik modellemesi için kullanılan analiz programlarından biri olan Lisrel istatistik analiz programı kullanılmıştır. Lisrel programı ile yapılan YEM, araştırılmak istenen ilişkisel modellerin, faktör analizi ve regresyonun bir arada kullanılarak test edilebilmesini kolaylaştıran bir metottur (Eroğlu, 2003).

Yapısal modelin Path diyagramı ile gösterimi;

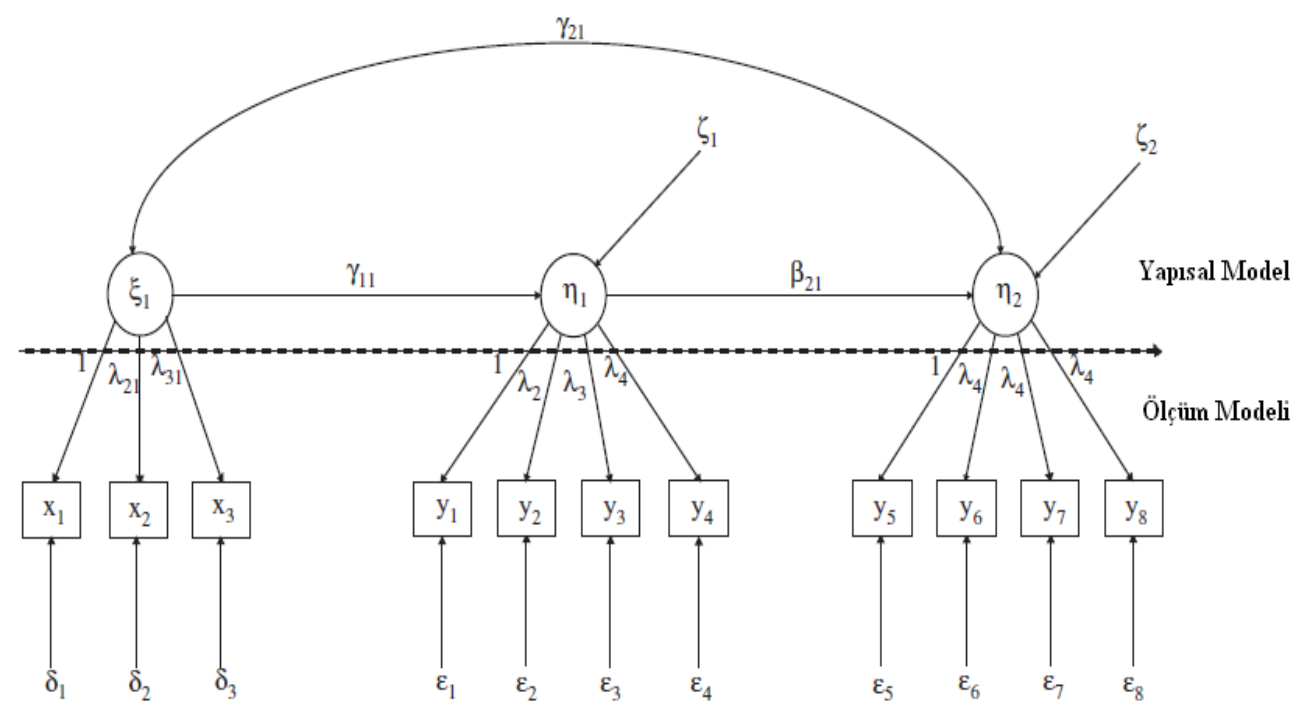

Şekil 2. Path diyagramı

YEM iki kısımdan oluşmaktadır. İlk kısmı gözlem değişkenlerini gizil değişkenlere doğrulayıcı bir faktör modeli ile bağlayan ölçüm modeli oluşturur. İkinci kısmı ise eş zamanlı denklemler sistemiyle gizil değişkenleri birbirine bağlayan yapısal model oluşturur (Kaplan, 2000:5). YEM’e göre gözlenen değişkenlerin, gizil değişkenler üzerinde açıklayıcı bir etkisi bulunmamaktadır. Aksine her bir gizil değişken kendi gözlenen değişkenleri üzerinde açıklayıcı bir etkiye sahiptir (Sümer, 2000:55). Ölçüm modelinde gözlenen değişkenler ve gizil değişkenler arasında bir ilişki sağlandığ 1 gibi, gözlenen değişkenlerin gizil değişkenleri ne kadar temsil ettiğinin açıklanmasında da bu modelden faydalanılır. Yapısal modelde ise araştırmacı bulguları ortaya çıkarmak istemektedir. $\mathrm{Bu}$ modelde gizil değişkenlerin değerlerinin, diğer gizil değişkenlerin değerleri üzerindeki etkilerinin doğrudan ya da dolaylı olarak doğurduğu sonuçlar belirtilmektedir (Byrne, 2001:12). 
Araştırma için çeşitli parametreler hesaplanır ve ulaşılmış olan bulguların elde edilmiş olan verilerle uyumunun sinanması gereklidir. YEM bu parametrelerin verilerle sinandığ modellerden biridir ve model birçok uyum indeksleri ile sınanır.

Uyum testleri, teorik olarak belirtilmiş olan modelin kovaryans matrisi ile örneklem kovaryans matrisinin karşılaştırılması ile sınanır. Teorik olarak belirtilenlerin test edilmesi sonucu, matrisler arasındaki fark fazla çıkarsa, matrislerin birbirlerine benzemediği ve böylece daha önce belirtilen teorik modele uygun olmadığı sonucuna ulaşılır. Matrisler arasındaki fark az olarak test edilirse, verinin teorik modele uygun olduğu sonucu ortaya çıkar. Sonuç olarak yapılan analiz ile ortaya çıkan uyum indeksleri, model ile veri arasında uyum olduğunu gösteriyorsa, model kabul edilir, uyum olmadığını gösteriyorsa model reddedilir (Karagöz 2016; 968).

Yaygın olarak kullanılan uyum istatistiği Ki-Kare (Chi-Square, $\chi^{2}$ ) Uyum Testi'dir. Bu test ile ulaşılan değerin 0'a yakın ve p değerinin anlamlı olmaması beklenir. Böylece veri ile model arasında çok iyi bir uyum olduğu belirtilebilmektedir. Burada bilinenin aksine anlamlılık testi, anlamlı olmayan bir "p" değeri ile elde edilmek istenmektedir. Elde edilen büyük $\chi^{2}$ değeri uyumun kötü olduğunu gösterir. Serbestlik derecesi (sd) büyük olursa $\chi^{2}$ anlamlı sonuçlar verme eğiliminde olup, serbestlik derecesi önemli bir ölçüttür. Bu nedenle bazı durumlarda serbestlik derecesinin $\chi^{2}$ ye oran yeterli bulunulabilmektedir. $1 / 3$ ve daha düşük oranlar iyi uyum, 1/5'e kadar olan oranlar ise yeterli uyum olarak açılanabilmektedir (Sümer, 2000:59-60). Uyum iyiliği indeksi (Goodness of Fit Index) GFI, modeldeki açıklanan genel varyansın toplam varyansa oranını göstermektedir (Erkorkmaz vd., 2013:213-214). Veri sayısı arttıkça ayarlanmış uyum iyiliği indeksi (Adjusted Goodness of Fit Index) AGFI temsil oranı daha iyi bir indekstir. GFI ve AGFI indeksleri 0 ile 1 arasında bir değer alır. 1'e yakın olan değerler modelde uyumun iyi olduğunu gösterir (Raykov ve Marcoulides, 2006:43). Yaklaşık Hataların Ortalama Karekökü (Root Mean Square Error of Approximation) RMSEA, Ana kütledeki gözlenen değişkenler arasındaki farkın yaklaşık uyumunun bir ölçüsüdür. 0 ile 1arasında bir değer alır. 0,05'ten küçük olması mükemmel uyumu, 0,05-0,08 arasında olması iyi uyumu ve 0,08'den fazla olması kabul edilebilir uyumu göstermektedir. Karşılaştırmalı Uyum İndeksi (Comparative Fit Index) CFI, gizil değişkenler arasında hiçbir ilişkinin olmadığını varsayarak, oluşturulan modelin kovaryans matrisi ile önerilen YEM modelinin ürettiği kovaryans matrisinin farkını verir. 0 ile 1 arasında bir değer alır. 0.90 ve üzerindeki değerler iyi uyumu göstermektedir (Sümer, 2000:61). Normlaştırılmamış Uyum İndeksi (Non-normed Fit Index) NNFI, modelde elde edilen ki-kare değeri ile değişkenler arasında ilişki olmadığını varsayar. Ki-kare değeri arasındaki farkı, serbestlik dereceleri ile göstermek 
için hesaplanmaktadır. CFI'ye alternatif bir indekstir. NNFI değerleri de 0 ile 1 arasında bir değer almaktadır. 0,95 üzerindeki değerler iyi uyumu, 0.90 ile 0.94 arasındaki değerler ise kabul edilebilir uyumu göstermektedir (Raykov ve Marcoulides, 2006:44).

\section{4. ÖRNEKLEM VE VERİ TOPLAMA}

Araştırmanın örneklemini Sivas ilinde bulunan özel ve kamu bankalarının şubelerinde çalışan personel oluşturmaktadır. Çalışmada, yaş, cinsiyet, gelir durumu, çalışma yılı gibi demografik sorular ve örgütsel adalet, örgütsel bağl1lık ve örgütsel güven ile ilgili 44 sorunun yer aldığı bir anket formu hazırlanmıştır. Ankete ilişkin Cronbach Alpha katsayısı 0,93 çıkmış olup, anketin güvenirliliğinin yüksek olduğu anlaşılmaktadır. Çalışmada ifadeler 5'li likert ölçeği içe ölçülmüştür (1- kesinlikle katılmıyorum, 2- katılmıyorum, 3- kararsızım, 4katılıyorum, 5- kesinlikle katılıyorum). Örgütsel adalet ile ilgili kullanılan anket soruları Niehoff ve Moorman (1993) tarafindan geliştirilen “Örgütsel Adalet Ölçeği”nden yararlanılarak, daha önceki çalışmalarda, Eğilmezkol (2011), İşbaşı (2000) ve Dilek'in (2004) Türkçe'ye çevirerek kullandığı anket ifadelerinden oluşmaktadır. Örgütsel adalet kavramı ölçeğinde yer alan üç alt boyuttan etkileşimsel adalet, dağıtımsal adalet ve işlemsel adalet alt boyutları ankette yer almış olup, bu üç boyuta dayalı verilen cevaplar neticesinde yapılan analizlerde etkileşimsel adalet ve işlemsel adalet alt boyutları anlamlı bir etkiye sahip olmadığından modele dahil edilmemiştir. Böylece; anlamlı bulunan alt boyut olan dağıtımsal adalet ile çalışılmış ve örgütsel adalet kavramını açıklamak için modelde dağıtımsal adelete ilişkin sorular değerlendirilmiştir. Örgütsel bağglılık ile ilgili çalışmada kullanılan anket soruları bu alanda yapılan çalışmalarda en çok kullanılan ölçek olan Allen-Meyer'in (1990) geliştirdiği üç boyutlu örgütsel bağlılık ölçeğinden yararlanılarak oluşturulmuştur. Örgütsel bağlılık; duygusal bağlılık, devam bağlılığı ve normatif bağlılık olmak üzere üç alt boyutta ele alınmaktadır. Bu ölçek; Baysal ve Paksoy tarafindan Türkçe'ye çevrilip, güvenirlilik çalışması yapılmıştır (Baysal ve Paksoy, 1999:7). Örgütsel güven için ise Bromiley ve Cummings (1996) ölçeği çeviri yapılarak uygulanmıştır. Çalışmada geçerli olarak değerlendirilen toplam 130 banka personeline ait veriye ulaşılmıştır. Verilerin yaş, cinsiyet, medeni durum, öğrenim durumu, çalışılan pozisyon, çalışılan servis, aylık gelir ve kurumda çalışılan yıllara göre demografik özellikler Tablo-1'de verilmiştir. 
Tablo 1- Demografik özellikler

\begin{tabular}{|c|c|c|c|}
\hline Değişkenler & Gruplar & $\bar{n}$ & $\%$ \\
\hline \multirow[t]{5}{*}{ Yaş } & $24-29$ & 24 & 18,5 \\
\hline & $30-35$ & 51 & 39,2 \\
\hline & $36-41$ & 38 & 29,2 \\
\hline & $42-47$ & 15 & 11,5 \\
\hline & $48+$ & 2 & 1,5 \\
\hline \multirow[t]{2}{*}{ Cinsiyet } & Kadın & 64 & 49,2 \\
\hline & Erkek & 66 & 50,8 \\
\hline \multirow[t]{3}{*}{ Medeni durum } & Evli & 94 & 72,3 \\
\hline & Bekar & 35 & 26,9 \\
\hline & Diğger & 1 & 0,8 \\
\hline \multirow[t]{4}{*}{ Öğrenim durumu } & İlköğretim & 2 & 1,5 \\
\hline & Lise & 14 & 10,8 \\
\hline & Üniversite & 106 & 81,5 \\
\hline & Diğger & 8 & 6,2 \\
\hline \multirow[t]{4}{*}{ Çalışılan pozisyon } & Memur & 73 & 56,2 \\
\hline & Yetkili & 45 & 34,6 \\
\hline & 2. Müdür & 10 & 7,7 \\
\hline & Müdür & 2 & 1,5 \\
\hline \multirow[t]{4}{*}{ Çalışılan servis } & Gişe & 35 & 26,9 \\
\hline & Operasyon & 39 & 30 \\
\hline & Bireysel kredi & 31 & 23,8 \\
\hline & Ticari kredi & 25 & 19,2 \\
\hline \multirow[t]{7}{*}{ Aylık gelir } & 2000'den az & 14 & 10,8 \\
\hline & $2000-3000$ 'den az & 53 & 40,8 \\
\hline & $3000-4000$ 'den az & 25 & 19,2 \\
\hline & $4000-5000$ 'den az & 19 & 14,6 \\
\hline & $5000-6000$ 'den az & 11 & 8,5 \\
\hline & $6000-7000$ 'den az & 7 & 5,4 \\
\hline & 10000 ve üzeri & 1 & 0,8 \\
\hline \multirow[t]{4}{*}{ Kurumda çalışılan yıl } & $1-6 \mathrm{y} 1 \mathrm{l}$ & 39 & 30 \\
\hline & $7-12$ yll & 53 & 33,1 \\
\hline & $13-18$ y1l & 36 & 27,7 \\
\hline & $19-24$ yil & 12 & 9,2 \\
\hline
\end{tabular}

Araştırma örneklemini oluşturan kişilerden \%39,2 bir paya sahip en büyük grup 31-35 yaş arası çalışanlar olup, katılımcıların \%49,2 ile 63'ünü kadın personel, \%50,8 ile 66'sını ise 
erkek personel oluşturmaktadır. \%72,3 ile 94 personel evli olduğunu, \%26,9 ile 35 personel ise bekar olduklarını belirtmişlerdir. Öğrenim durumu açısından bakıldığında personelin çoğunluğunun \%81,5 ile üniversite mezunu oldukları söylenebilir. Yine çalışanların çoğunluğunu \%56,2 ile memur kadrosunda çalışanlar oluşturmaktadır. Çalışılan servis açısından değerler birbirine yakındır. \%26,9'u gişede, \%30'u operasyonda, \%23,8'i bireysel kredi servisinde ve \%19,2'si ise ticari kredi servisinde çalışmaktadır. Aylık gelir bakımından en çok gelir dağılımı \%40 ile 2000-3000'den az olan kısımdadır. Yine kurumda çalışma yılı olarak bakıldığında en çok çalışılan yıl olarak 7-12 yıl arası \%33,1'lik bir paya sahiptir. 1-6 yıl arası çalışanlar \%30, 13-18 yıl arası çalışanlar ise \%27,7'lik kısmı oluşturmaktadır. Bu durum ise bankada çalışan personelin genel olarak genç olduğunu göstermektedir.

\section{ANALIZ VE BULGULAR}

Yapısal eşitlik modellemesinde, veri setinin çok değişkenli normal dağılım gösterip göstermediği değerlendirilmelidir. Bu amaçla, Mardia’nın (1970) testine dayanarak, LISREL aracılığı ile yapılan çok değişkenli Mardia test sonucu $\mathrm{p}<0,001$ olarak bulunmuş ve çalışmada toplanan verinin çok değişkenli normallik varsayımını sağlamadığı tespit edilmiştir. $\mathrm{Bu}$ durumda tahminlerin elde edilmesinde çoklu normallik varsayımının sağlanamadığı örnekler için önerilen parametre tahmin yöntemi olan "Robust Maximum Likelihood" yöntemi kullanılmıştır.

Yapısal eşitlik modellemesinde, geçerlilik ve güvenirlik için değerlendirilen farklı kriterler bulunmaktadır. Bunlardan ilki yapı geçerliliği ile ilgili olan ve gizil değişkenlere ait her bir gözlenen değişkenin standart faktör yükünün $0,5^{\prime}$ den büyük ve istatistiksel olarak anlamlı olması gereğidir. Yakınsak ve diskriminant geçerliliği için ise; gizil yapıdaki gözlenen değişkenler arasındaki yakınsamanın bir ölçüsü olan Ortalama Açıklanan Varyans (AVE) değerleri kullanılır ve bu değerin 0.50’nin üstünde olması istenir. Güvenirlik için en yaygın kullanılan krtiter Cronbach's alpha değerinin 0.70'in üstünde olmasıdır. Yapısal eşitlik modellemesinde ayrıca; gizil bir yapıyı temsil eden değişken ölçümlerinin iç tutarlılığı sağlaması anlamına gelen yapı güvenirliği (CR) de kullanılan bir diğer kriterdir. Yap1 güvenirliği için bu değerin de 0.70'in üstünde olması gerekmektedir (Hair, Anderson, Tatham, \& Black, 1998:612). Çalışmada önerilen modelde yer alan değişkenler ile bunlara ait geçerlilik ve güvenirlik değerleri Tablo-2'de yer almaktadır. Bu değerler incelendiğinde çalışmada oluşturulan modele ait standart faktör yükleri 0,68 ile 0,96 arasında değer alarak gizil ve 
gösterge değişkenler arasında zayıf ilişki olmadığını göstermektedir. Ayrıca, CR ve CA değerleri 0,81 ve üstü değerler alarak 0.70 'in üstünde olma kriterini sağlamıştır. Son olarak ortalama açıklanan aaryansı belirten AVE değerlerinin tümü 0,5 'in üzerinde hesaplanaral yakınsak ve diskriminant geçerliliği sağlanmıştır.

Tablo 2- Araştırma Modeline İlişkin Sonuçlar

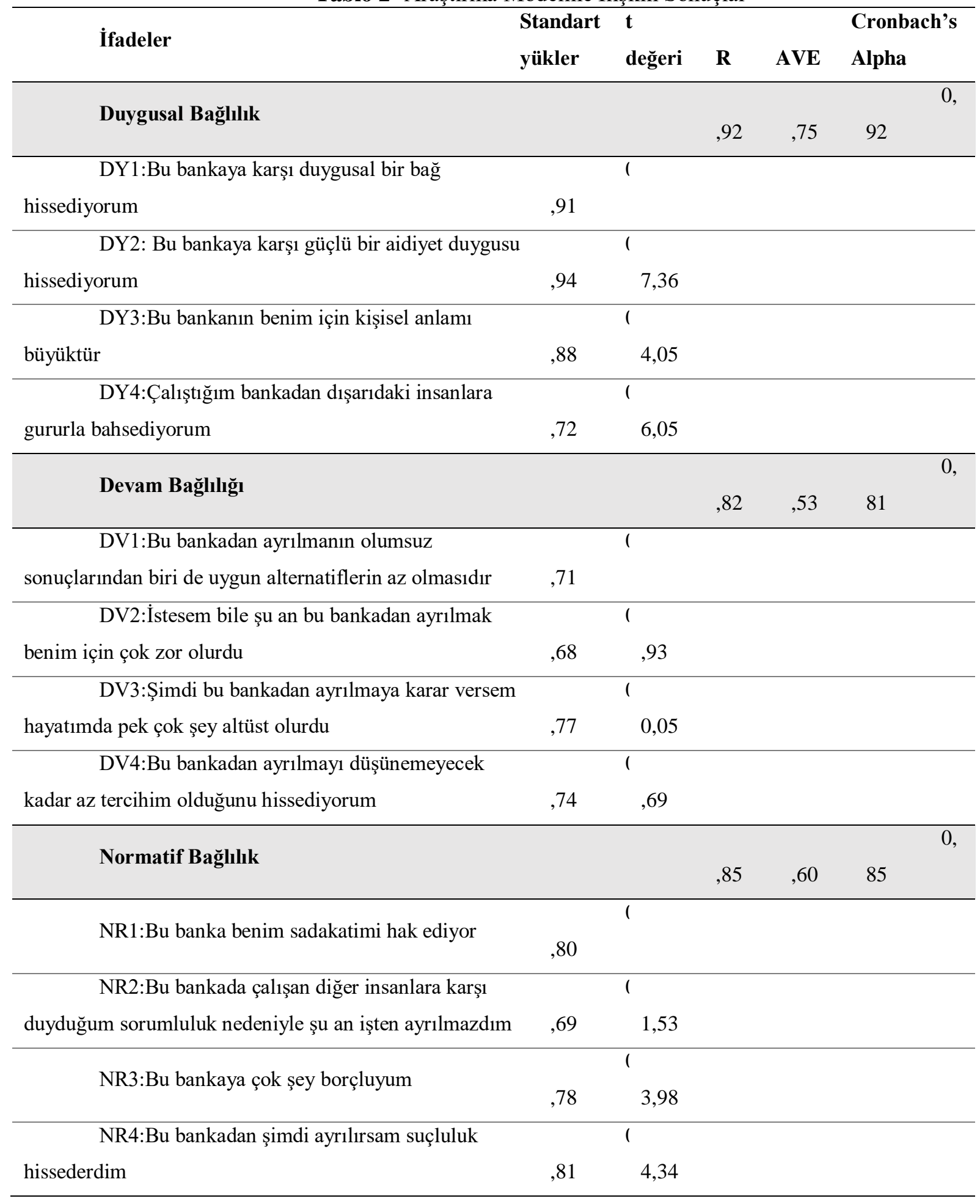




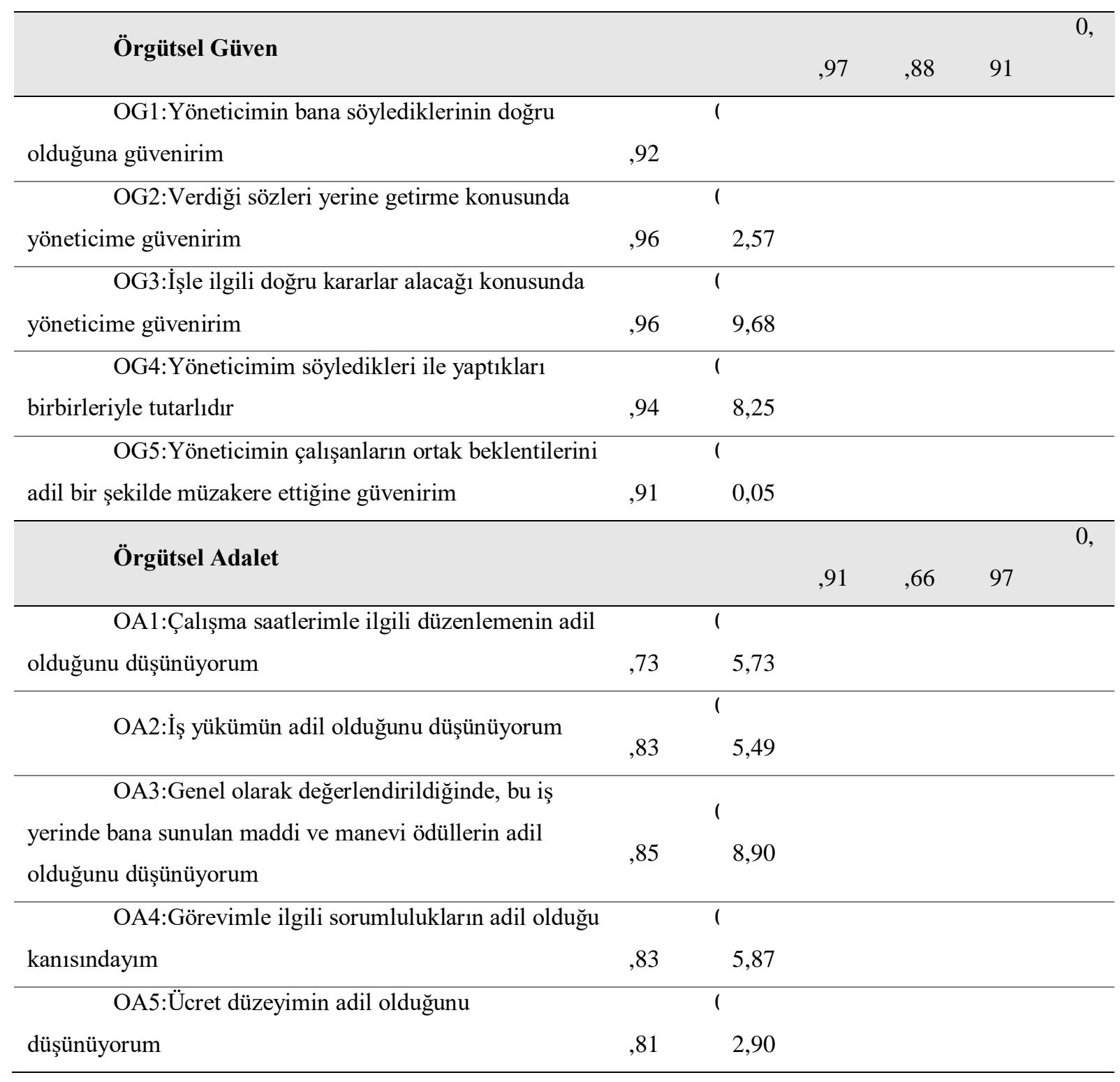

Çalışmada önerilen araştırma modeli için hesaplanan uyum indeksleri modelin kabul edilebilir ve uygun bir model olduğunu göstermektedir. Uyum indekslerinden biri olan $\chi^{2} / \mathrm{sd}=$ 409,89/205=1,99 değeri 3'ten küçük olup uyumun iyi olduğunu belirtmektedir. Model için hesaplanan GFI değeri 1'e ne kadar yakınsa uyumun o kadar iyi olduğu yönünde değerlendirilir ve çalışmadaki model için 0,78 olarak hesaplanmıştır. Yaklaşık Hataların Ortalama Karekökü (Root Mean Square Error of Approximation) RMSEA değeri 0,08 bulunmuş olup 0,05-0,08 arasında olması iyi uyumu ve 0,08 'den fazla olması kabul edilebilir uyumu göstermektedir. CFI ve NNFI değerlerinin her ikisi de 0,96 olarak elde edilerek iyi uyum olduğunu belirtmektedir. Son olarak tüm uyum indeksleri birlikte değerlendirildiğinde; oluşturulan modelin kabul edilebilir ve iyi uyum gösteren bir model olduğu belirlenmiştir. 
Tablo 3 incelendiğinde H1, H2, H3 ve H4 hipotezleri istatistiksel olarak t değeri $\% 5$ anlamlılık düzeyinde kabul edilmiştir. Örgütsel adalet ile örgütsel güven arasında, örgütsel güven ile duygusal bağl1lık arasında, örgütsel güven ile devam bağlılığı arasında ve örgütsel güven ile normatif bağlılık arasında pozitif yönlü bir ilişki olduğu belirlenmiştir. Bu verilere göre örgütsel adaletteki bir birimlik artış örgütsel güven de 0,48 birimlik bir artışa neden olmaktadır. Aynı şekilde örgütsel güvendeki bir birim artış; duygusal bağlılık üzerinde 0,50 birimlik, devam bağl1lığ üzerinde 0,23 birimlik ve normatif bağlılık üzerinde 0,55 birimlik bir artış sağlamaktadır.

Hesaplanan $\mathrm{R}^{2}$ değerlerine göre güvendeki değişimin yüzde 23 'ünün adalet faktörü tarafından açıklandığı sonucu ortaya çıkmıştır. Aynı şekilde güven, sırasıyla duygusal faktörünün yüzde $25^{\prime}$ 'ini, devam faktörünün yüzde 0,054 'ünü ve normatif faktörünün yüzde 0,30’unu açıklamaktadır.

Tablo 3- Hipotez Sonuçları

\begin{tabular}{|c|c|c|c|c|}
\hline & \multicolumn{4}{|c|}{ parametre tahminleri } \\
\hline güven & H1: Örgütsel adalet \& Örgütsel & 0,48 & 6,36 & Kabul edildi \\
\hline bağlılık & H2: Örgütsel güven \& Duygusal & 0,50 & 7,13 & Kabul edildi \\
\hline bağlılığ & H3: Örgütsel güven \& Devam & 0,23 & 2,43 & Kabul edildi \\
\hline bağlılık & H4: Örgütsel güven \& Normatif & 0,55 & 7,10 & Kabul edildi \\
\hline & $\begin{array}{r}\text { Gı } \\
\text { Duy } \\
\text { De } \\
\text { Nor }\end{array}$ & $\begin{array}{l}\text { en }=0.48 * \text { Adalet, } R^{2} \\
\text { usal }=0.50 * \text { Guven, } R \\
\text { am }=0.23 * \text { Guven, } R^{2} \\
\text { latif }=0.55 * \text { Guven, } R\end{array}$ & & \\
\hline
\end{tabular}

Yapılan analizler sonucu path diyagramı Şekil 3'deki gibi elde edilmiştir. 


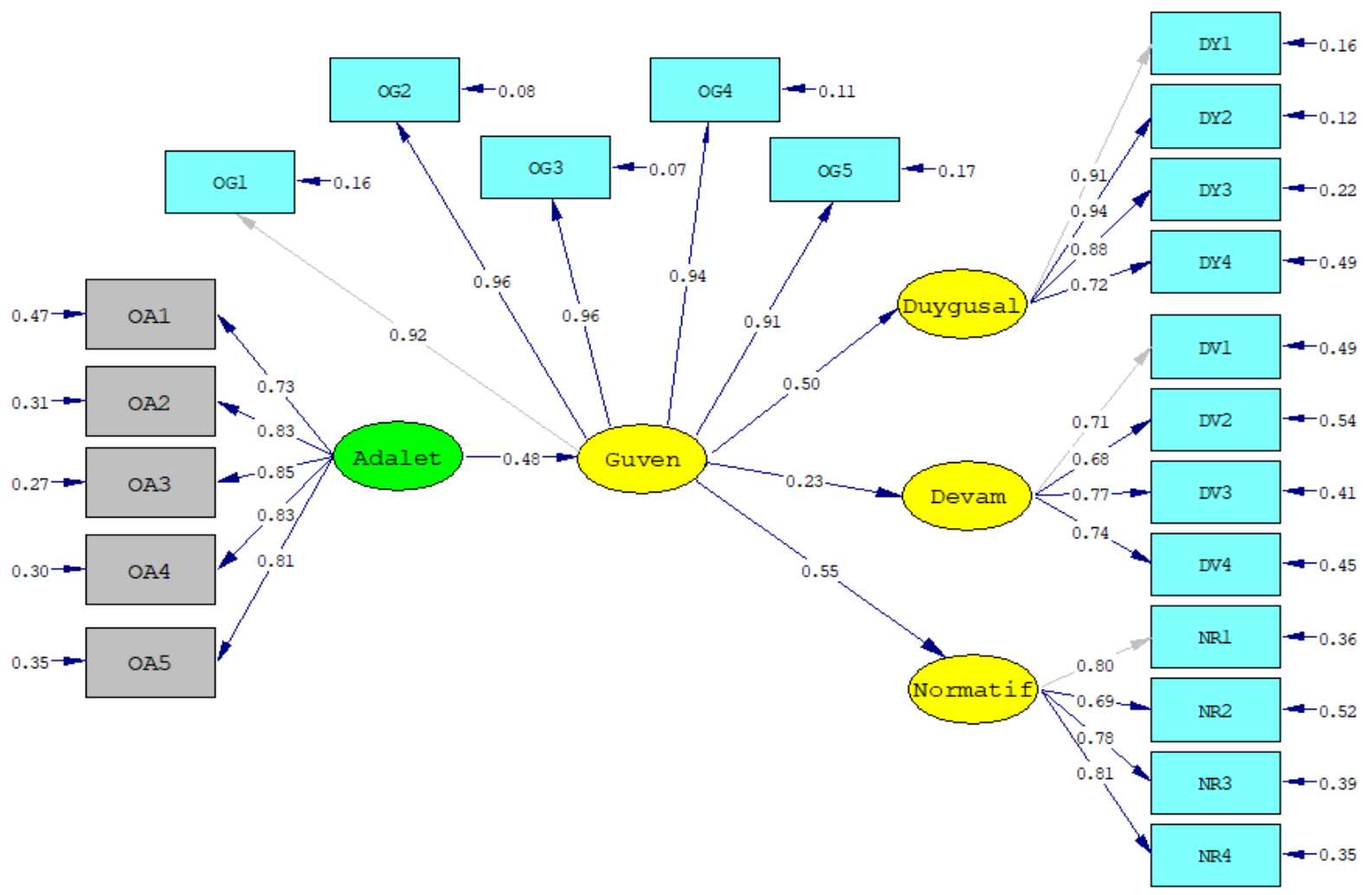

Şekil 3. Path Diyagramı (Lisrel 8.72 ekran görüntüsü)

\section{SONUÇ VE TARTIŞMA}

Bu çalışma ile bankacılık sektöründe çalışan personelin örgütsel adalet ile ilgili olarak kurumun ve yöneticilerin çalışanlara adaletli davranmaları üzerine algıları, adaletli davranışların örgütsel güven üzerine algıları ve örgüte duyulan güvenin ise örgütsel bağlılık üzerine algıları arasındaki ilişkinin tespit edilmesi amaçlanmıştır. Örgütsel adalet kavramı; alt boyutu olan dağıtımsal adalet ile açıklanmıştır. Bunun nedeni çalışmanın örnekleminin çoğunluğunu alt tabakadaki personelin oluşturması ve ücret, çalışma saati, iş yükü gibi kavramların alt tabakadaki personel üzerinde daha fazla etkisinin olmasından dolayıdır. Örgütsel güven tek başına açıklanmış olup, örgütsel bağlılık kavramı, üç alt boyutu olan duygusal bağlılık, devam bağlılı̆̆ ve normatif bağl1lık ile açıklanmıştır.

Araştırmanın kapsamını Sivas ilinde bulunan kamu ve özel banka şubelerindeki personel oluşturmaktadır. Örgütsel adalet, örgütsel güven ve örgütsel bağl1lık arasındaki ilişkiyi ölçmek için anket formu düzenlenmiştir. Toplamda geçerli olarak 130 personele ait veri değerlendirilmiştir. 
Çalışmanın güvenirlik testi yapılmıştır. Güvenirlik katsayısı Cronbach’s Alpha değeri 0,934 olarak hesaplanmış ve anketin güvenirlilik düzeyinin yüksek olduğu gözlemlenmiştir. Çalışmada 4 hipotez kurulmuştur. Kurulan hipotezlerin hepsi test edilerek kabul edilmiştir. H1 hipotezi, örgütsel adalet ve örgütsel güven arasındaki ilişkiyi test etmektedir. Test sonucuna göre bu iki kavram arasında anlamlı bir ilişki olduğu gözlemlenmiştir. Bunun anlamı çalışanlar üzerinde çalışma saati, iş yükü, ücret gibi konularda adaletli yaklaşım, örgüte olan güveni pekiştirmektedir. H2 hipotezi, Örgütsel güven ve duygusal bağlılık arasındaki ilişskiyi tespit etmektedir ve hipotez kabul edilerek aralarında anlamlı bir ilişki olduğunu göstermektedir. Buna göre örgüte duyulan güven personel üzerinde aidiyet duygusunu güçlendirmekte olup, örgüte olan bağl1lık üzerinde etkisi olduğu gözlemlenmiştir. H3 hipotezi, örgütsel güven ve devam bağlılığını test ederek, aralarında anlamlı bir ilişki olduğunu ortaya koymaktadır. Bunun anlamı kuruma olan güven, çalışmayı teşvik edici bir unsurdur ve çalışanların örgütte devam etmesi üzerine etkilidir. Fakat diğer hipotezlere göre örgütsel güven ile devam bağl1lı̆̆1 arasındaki ilişki 0,23 ile en düşük etkiye sahiptir. H4 hipotezi, örgütsel güven ve normatif bağlılık arasındaki ilişkiyi test etmektedir. Testin sonucuna göre bu iki kavram arasında anlamlı bir ilişki görülmektedir. Örgütsel güven ve normatif bağlılık arasındaki bu ilişki, çalışan personel üzerinde örgütün sağladığı güvenin, kuruma olan sadakatini etkilediği anlamını taşımaktadır. Bu iki kavram arasındaki ilişki 0,55 ile en büyük etkiye sahiptir.

$\mathrm{Bu}$ çalışmadan elde edilen sonuçlar 1şığında banka yöneticilerine, çalışanların iş yerlerinde adaletli bir iş dağılımı olduğu düşüncesinin çalıştıkları bankaya olan güveni arttıracağ 1 ve bunun da çalıştıkları bankaya olan bağl1lık üzerinde olumlu bir etkisi olacağı; bu bağlamda çalışanların daha mutlu ve verimli çalışacakları söylenebilir. Ayıca bu sonuçların; benzer konuda çalışma yaparak söz konusu bu üç kavramı birlikte modellemek isteyen araştırmacılar için yol gösterici ve başlangıç çalışması olarak değerlendirilebileceği düşünülmektedir. 


\section{KAYNAKÇA}

Akgündüz, Y. \& Güzel, T. (2014). Örgütsel Adalet ile Örgütsel Bağl1lık Arasındaki İlişkide

Örgütsel Güvenin Aracılık Etkisi. Anadolu Üniversitesi Sosyal Bilimler Dergisi, Cilt/Vol.: 14Sayı/No:3, 1-18.

Aksoy, C. (2017). Çalışanların Örgütsel Adalet ve Örgütsel Güven Algıları Arasındaki İlişkinin İncelenmesi. International Journal of Management and Administration, Y11:1, Cilt:1, Say1:1.

Allen, N. J. \& Meyer, J. P. (1990). The measurement and antecedents of affective, continuance and

normative commitment to the organization. Journal of Occupational Psychology, 63, 1-18.

Baysal, A. C. \& PAKSOY M. (1999). Mesleğe ve örgüte bağlılı̆̆ın çok yönlü incelenmesinde Meyer-Allen modeli. İstanbul Üniversitesi İşletme Fakültesi Dergisi, 28 (1), 7-15.

Bromiley, P. \& Cummings L.L. (1996). The Organizational Trust Inventory (OTI) Roderick M.

Kramer ve Tom R. Tyler (Der.). Trust in Organizations, Thousand Oaks: Sage, 302-319.

BYRNE, M. Barbara (2001), Structural equation modeling with amos basic concepts, applications, and

Programming. Lawrence Erlbaum Associates Inc, New Jersey.

Candan, H. (2014). Çalışanların Örgütsel Adalet ve Örgütsel Güven Algılamalarının Örgütsel Bağlılı̆ga

Etkisi: Bir Kamu Kurumu Üzerinde Araştırma. Gaziantep Üniversitesi Sosyal Bilimler Dergisi, 13(4), 889-917.

Chen, T.Y., Hwang, S.N. \& Liu, Y. (2012). Antecedents of the voluntary performance of employees: Clarifying the roles of employee satisfaction and trust. Public Personnel Management, 41 (3), 407-420.

Cook, J. \& Wall, T. (1980), New Work Attitude Measures of Trust, Organizational Commitment and 
Personal Need Non-Fulfilment. Journal of Occupational Psychology, 53, 39-52

Çakar, D.N. \& Ceylan A. (2005). İş Motivasyonunun Çalışan Bağlılığ ve İşten Ayrılma

Eğilimi Üzerindeki Etkileri. Doğuş Üniversitesi Dergisi, Cilt 6, Sayı 1, 52-66, İstanbul.

Çelik, H. E. \& Yılmaz, V. (2016). Lisrel 9.1. ile Yapısal Eşitlik modellemesi, Temel KavramlarUygulamalar- Programlama. Ankara: Anı Yayıncılık.

Demirel, Y. (2008). Örgütsel Güvenin Örgütsel Bağl1lık Üzerine Etkisi: Tekstil Sektörü Çalışanlarına

Yönelik Bir Araştırma. Yönetim ve Ekonomi, Cilt:15 Sayı:2.

Dilek, U. (2004). Örgütsel Adalet Algılamaları ve Örgütsel Bağlılıkla İlişkisi (Yüksek Lisans Tezi). Kara Harp

Okulu Savunma Bilimleri Enstitüsü, Ankara.

Eğilmezkol, G. (2011). Çalışma Yaşamında Örgütsel Adalet ve Örgütsel Bağl1lık: Bir Kamu

Bankasındaki Çalışanların Örgütsel Adalet ve Örgütsel Bağlılık Algılayışlarının Analizine Yönelik Bir Çalışma (Yüksek Lisans Tezi). T.C. Gazi Üniversitesi Sosyal Bilimler Enstitüsü İşletme Anabilim Dalı Genel İşletme Bilim Dalı, Ankara.

Erkorkmaz, Ü., Etikan, İ., Demir, O., Özdamar, K. \& Sanisoğlu, S.Y. (2013).

Doğrulayıc1 Faktör Analizi ve Uyum İndeksler. Türkiye Klinikleri J Med Sci, 33(1).

Eroğlu, E. (2003). Toplam Kalite Yönetimi Uygulamalarının Yapısal Eşitlik Modeli İle Analizi (Doktora Tezi). T. C.

İstanbul Üniversitesi Sosyal Bilimler Enstitüsü İşletme Anabilim Dalı Sayısal Yöntemler Bilim Dalı, İstanbul.

Greenberg, J. A. (1993). The social side of fairness: Interpersonal and Informational Classes of Organizational Justice. R. Cropanzano (Ed.). Justice in The Workplace: Approaching Fairness iHuman Resource Management, NJ: Lawrence Erlbaum; 79-103.

Gülova, A. A. \& Demirsoy Ö. (2012). Örgüt Kültürü ve Örgütsel Bağlılık Arasındaki İlişki:

Hizmet Sektörü Çalışanları Üzerinde Ampirik Bir Araştırma. Business and Economics Research Journal, Volume 3 Number 3 2012, 49-76. 
Hair, J. F., Anderson, R.E., Tatham, R.L. \& Black, W.C. (1998). Multivariate data analysis (5.ed.). New Jersey: Prentice Hall, Işık, O., Uğurluoğlu, Ö. \& Akbolat M. (2012). Sağlık Kuruluşlarında Örgütsel Adalet Algılarının Örgütsel Bağlılığa Etkisi. Doğuş Üniversitesi Dergisi, 13 (2) 2012, 254-265 İnan, İ. E. \& Çelik, E. (2018). Algılanan Örgütsel Güven ve İş Tatmini: Kastamonu İli Özel ve Kamu Bankalarında Bir Uygulama. Al-Farabi Uluslararası Sosyal Bilimler Dergisi, Vol. $2 / 3$.

İşbaşı, J.Ö. (2000). Çalışanların Yöneticilerine Duydukları Güvenin ve Örgütsel Adalete İlişkin Algılamalarının Örgütsel Vatandaşlık Davranışının Oluşumundaki Rolü: Bir Turizm Örgütünde Uygulama (Yüksek Lisans Tezi). Akdeniz Üniversitesi Sosyal Bilimler Enstitüsü İşletme Anabilim Dalı, Antalya.

Kaplan, D. (2000). Structural equation modeling foundations and extensions. California: Sage Publications.

Karagöz, Y. (2016). Spss 23 ve Amos 23 Uygulamalı İstatistiksel Analizler. Ankara:Nobel Yayıncilık.

Kaya, N. \& Selçuk, S. (2007). Bireysel Başarı Güdüsü Organizasyonel Bağlılığı Nasıl Etkiler?. Doğuş

Üniversitesi Dergisi, 8 (2),175-190.

Khan, S. \& Usman, H. (2012). Procedural Justice \& Organizational Performance. Abasyn Journal

of Social Science, Volume: 4, Issue:1,36-51.

Mete, M. \& Aksoy, C. (2015). Çalışanların Adalet Algıları Acısından Örgütsel Güven ile Örgütsel

Bağlılığın Karşılaştırılması: Bankacılık Sektöründe Bir Uygulama. Elektronik Sosyal Bilimler Dergisi, Yaz-2015 Cilt:14 Say1:54,233-246.

Meyer, J.P. \& Allen, N.J. (1991). A Three-Component Conceptualization of Organizational Commitment. Human Resource Review, 1(1),61-89. 
Niehoff, B. P. \& Moorman, R. H. (1993). Justice As A Mediator of The Relationship Between

Methods of Monitoring and Organizational Citizenship Behavior. Academy of Management Journal, 36, 527-556.

Oktay, E. \& Gül, H. (2003). Çalışanların Duygusal Bağlılıklarının Sağlanmasında Conger ve

Kanungo'nun Karizmatik Lider Özelliklerinin Etkileri Üzerine Karaman ve Aksaray Emniyet Müdürlüklerinde Yapılan Bir Araştırma. Selçuk Üniversitesi Sosyal Bilimler Enstitüsü Dergisi, Sayı 10, 403-427.

Polatçı, S., Ardıç, K. \& Türkan, G. (2014). Bağlılık Boyutlarının Tükenmişlik Boyutları

Üzerindeki Etkisinin İncelenmesi. Yönetim ve Ekonomi, cilt 21, say1 2.

Raykov, T. \& Marcoulides, A.G. (2006). A first course in structural equation modeling (2.ed.).

New Jersey:Lawrence Erlbaum Associates Inc.

Sümer, N. (2000). Yapısal eşitlik modelleri: temel kavramlar ve örnek uygulamalar. Türk Psikoloji Yazıları,

$3(6), 49-7$.

Şahin, B. \& Taşkaya, S. (2010). Sağlık Çalışanlarının Örgütsel Adalet Algılarını Etkileyen

Faktörlerin Yapısal Eşitlik Modeli ile İncelenmesi. Hacettepe Sağlık İdaresi Dergisi, Cilt:13, Say1:2.

Şahin, R. ve Kavas, E. (2016). Örgütsel Adalet ile Örgütsel Bağl1lık Arasındaki İlişkinin

Belirlenmesinde Öğretmenlere Yönelik Bir Araştırma: Bayat Örneği. Süleyman Demirel Üniversitesi Vizyoner Dergisi, Cilt: 7, Sayı: 14,119-140.

Uyar, A. (2019). Müşteri Memnuniyeti ile Müşteri Sadakati Arasındaki İlişkinin Yapısal Eşitlik Modeli ile

İncelenmesi: Otomobil Kullanıcıları Üzerine Bir Uygulama. Elektronik Sosyal Bilimler Dergisi, Kış, Cilt:18 Sayı:69,41-57.

Üstün, F. (2015). Örgütlerde sıkılık-esneklik boyutunun örgütsel güven, kurumsal girişimcilik ve firma 
performansına etkisi: Türkiye'nin öncü sanayi işletmeleri üzerine bir araştırma (Doktora Tezi). Çukurova Üniversitesi, Adana.

Yavuz, E. (2010). Kamu ve Özel Sektör Çalışanlarının Örgütsel Adalet Algılamaları Üzerine Bir

Karş1laştırma Çalışması. Doğuş Üniversitesi Dergisi, Cilt: 11, Sayı: 2,302 - 312, İstanbul.

Yıldız, K. (2013). Öğretmenlerin Örgütsel Adalet ve Örgütsel Güven Algıları. AİBÜ Sosyal Bilimler

Enstitüsü Dergisi, Bahar, Cilt:13, Y11:13, Sayı:1, 13,289-316.

Yüksekbilgili, Z., Çöpoğlu, M. \& Gür, O. (2015). Örgütsel Adalet: Bir Büyükşehir

Belediyesinde Araştırma. Elektronik Sosyal Bilimler Dergisi, Güz-2015, Cilt:14, Say1:55,4553. 